\title{
NAPAK TILAS PERSPEKTIF INDONESIASENTRIS JACOB CORNELIS VAN LEUR ${ }^{1}$
}

\author{
Daya Negri Wijaya \\ Jurusan Sejarah, Universitas Negeri Malang
}

\begin{abstract}
Abstrak: J.C. van Leur adalah salah satu orientalis yang turut memperkenalkan cara pandang dari dalam. Dia, seperti halnya tradisi Weberian, mencoba melihat modernitas dari kacamata masyarakat setempat. Dia menyanggah pendapat bahwa sejarah Nusantara adalah keberpengaruhan dari masyarakat Barat. Masyarakat Nusantara harus dilihat dari dinamika mereka sendiri. Baik masyarakat Barat maupun Timur telah mengalami modernisasi sekaligus menikmati modernitas pada masa tertentu. Asumsi inilah yang dia pakai untuk melihat perkembangan masyarakat Nusantara. Tulisan ini berupaya membahas kehidupan van Leur, pendekatan weberian dan historiografi Indonesiasentris, perdagangan dan embrio kapitalisme, Hinduisasi Nusantara, Islamisasi Nusantara, dan Oksidentalisme Nusantara.
\end{abstract}

Kata-kata kunci: historiografi modern, kapitalisme, Hinduisasi, Islamisasi, oksidentalisme

\begin{abstract}
J.C. van Leur is one of orientalists introducing the perspective from within. He, as like as the Weberian tradition, tries to look at the modernity from the surrounded society. He criticizes the argument of "the history of Nusantara is the continuation of the Western". The people should be viewed from their dynamics. Either occidental or oriental societies have face the modernization and the modernity in a different time. This assumption leads him to realize the development of Nusantara. This article will discusses the life of J.C. van Leur; the Weberian approach and Indonesia centric point of view; the trade and the substance of capitalism; Hinduization of Nusantara; Islamization of Nusantara; and Occidentalism of Nusantara
\end{abstract}

Keywords: modern historiography, capitalism, Hinduization, Islamization, Occidentalism

Dalam kehidupan sehari-hari, masyarakat lebih memilih untuk mengonsumsi hamburger, ayam goreng, kentang goreng, atau minuman ringan dengan label internasional daripada label nasional walaupun citarasa yang dihadirkan tidak terlalu kalah telak. Mereka beradu gengsi dengan gencar memakai produk asing untuk menunjukkan eksistensi mereka pada khalayak. Selain itu, Wijaya (2014) menjelaskan bahwa sadar ataupun tidak, kini Indonesia mengalami proses industrialisasi secara masif dari negara-negara maju. Salah satu contohnya, dalam jersey kebanggan klub sepak bola liga premier Inggris tertera keterangan bahwa jersey tersebut dibuat di Indonesia (made in Indonesia). Nampak telah terjadi industrialisasi global disini dimana untuk menekan biaya produksi suatu barang dan upah pekerja maka diputuskan untuk membuat pabrik di negara berkembang yang kiranya dipandang lebih murah dan hasil produksinya didistribusikan dengan harga yang berkali-kali lipat dan disebarkan ke seluruh penjuru dunia. Secara singkat terlihat bahwa masyarakat Indonesia secara sadar menjadi konsumen produk Barat, ironisnya kita mengidealkan cara pandang Barat.

Realitas tersebut tentu mencengangkan sekaligus sulit dipahami. Masyarakat tidak bisa keluar dari idealitas Barat. Apa yang terjadi di masa kini bukanlah suatu kebetulan tetapi dikonstruksi oleh masa lalu. Sejarah sebagai ilmu yang mempelajari masa lalu memiliki peran vital disini. Tatanan masyarakat selalu berubah sehingga ilmu sosial seperti sosiologi, antropologi, atau ekonomi tidak dapat melihat kondisi masyarakat terkini. Mereka memerlukan penjelasan mengenai perubahan dan

\footnotetext{
1 Artikel ini adalah pengembangan dari ceramah yang disampaikan dalam rangka Bedah Buku Karya J.C. van Leur, "Perdagangan dan Masyarakat di Indonesia" yang diselenggarakan oleh HMJ Sejarah FIS UM, di I1.401 Fakultas Ilmu Sosial, Universitas Negeri Malang, pada tanggal 11 Maret 2016
} 
kesinambungan masyarakat. Perubahan dan kesinambungan masyarakat hanya dapat dipahami dengan bantuan ilmu yang bersifat diakronis. Sejarah sebagai ilmu diakronik yang memanjang dalam waktu memberikan penjelasan mengapa masyarakat berubah dan kemana perubahan tersebut berakhir. Menurut Kuntowijoyo (2003:45), model diakronis akan menjadi pelengkap yang sempurna bagi penulisan sinkronis. Rangkaian kejadian yang susulmenyusul tidak saja menjawab mengenai apa yang ada, tetapi juga mengapa sesuatu ada dan bagaimana terjadinya. Penulisan sejarah merupakan suatu urutan dinamis atau dialektis dengan waktu yang jelas.

Salah satu karya sejarah yang kiranya dapat mendukung perspektif Indonesiasentris adalah karya Jacob Cornelis van Leur, berjudul Perdagangan dan Masyarakat Indonesia. Karya tersebut pertama kali diterbitkan pada tahun 1955 dalam Bahasa Belanda serta diterjemahkan dalam Bahasa Inggris pada tahun 1984 dan dalam Bahasa Indonesia pada tahun 2015. Karya van Leur ini menjadi klasik dalam pembelajaran sejarah sosial-ekonomi. Penulis sangat mengingat kala masih menempuh program sarjana hanya bisa sayup-sayup mendengar pemikirannya dari tangan orang ketiga bahkan orang keempat. Hal ini disebabkan karena pada waktu itu buku karya van Leur sangat jarang ditemukan di toko buku sehingga penulis tidak memiliki akses langsung pada pemikiran van Leur. Wajar apabila kemudian penulis sangat mengapresiasi kehadiran penerjemahan karya van Leur dalam Bahasa Indonesia sekaligus kepedulian Penerbit Ombak Yogyakarta yang mendorong perkembangan Ilmu Sejarah di Indonesia.

Menurut Van Niel (1956), karya van Leur adalah hasil disertasi dan pengembangan pemikirannya. Karya tersebut terdiri atas empat bagian. Bagian pertama adalah disertasinya yang berjudul "Some Observations Concerning Early Asian Trade" yang dipertahankan di Universitas Leiden (1934). Bagian kedua adalah kajiannya mengenai sejarah Hindia Belanda yang pernah dipublikasikan pada jurnal "Koloniale Studien" (1937). Bagian ketiga adalah beberapa bab yang seharusnya ingin dia publikasikan sebagai buku namun beberapa bab lainnya tidak sampai di Belanda karena ada perang. Bagian terakhir mengenai ulasannya mengenai Sejarah HindiaBelanda yang diedit oleh F.W. Stapel.

Selain itu, Dia melihat pengajian suatu masyarakat sudah seharusnya berangkat dari dalam masyarakat sendiri. Hal ini berarti bahwa ketika kita ingin menulis sejarah politik di Indonesia harus memulainya dengan analisis kondisi sosial dan ekonomi umum. Dua analisis tersebut dapat membantu menentukan rangkaian fakta-fakta yang unik. Dalam mengaji sejarah ekonomi, van Leur (2015:7) menekankan:

“...Untuk itu kita harus memulainya dari masa kapitalisme modern yang saat ini meninggalkan jejaknya di seluruh dunia...Tugas sejarah ekonomi adalah menentukan bagaimana kapitalisme modern dibangun, dan kapan, dimana pondasinya terbentuk, sejauh mana kapitalisme dapat dikatakan sebagai karya Eropa Barat, dan selain itu bagaimana periode-periode tersebut--yang keberadaannya dicirikan oleh struktur sosial dan ekonomi yang berbeda ditandai dalam periode kapitalisme modern, dan hal apa yang menjadi corak khas dari bentukbentuk tersebut. Semua material (sumber) yang terkumpul harus dipelajari terus menerus untuk dapat memahami pengaruh kapitalisme modern (yang besar dan mendominasi) dan untuk membandingkan periode terdahulu dengan periode itu. Untuk itu nilai penting jalur laut harus ditentukan, demikian juga perniagaan dan perdagangan, bentuk-bentuk organisasi, dan nilai penting kesemua hal tersebut bagi pondasi material sejarah budaya...”

Van Leur terlihat melihat perkembangan suatu peradaban didasarkan pada perkembangan kapitalisme. Sistem kapitalis inilah yang kemungkinan besar berhasil memperalat masyarakat Indonesia. Dengan keterbukaan masyarakat, para kapitalis dapat dengan mudah memenuhi segala kebutuhan dan harapan rakyat. Namun demikian, sistem ini, jika mengutip 
pendapat dari Wertheim (1954:170-1), kapitalisme telah membuat jurang pemisah antara peradaban Barat dan Timur. Dia melihat van Leur cenderung memberikan suatu ilustrasi bahwa hingga abad ke-19, perkembangan peradaban Eropa dan Asia masih setara namun berbagai pengaruh asing membuat orang Asia menjadi tertutup (berpikir imanen). Hasilnya mereka mengikuti arus yang ada dan tidak mampu mengembangkan peradabannya sendiri. Setidaknya sebelum abad ke-19, kesetaraan antara Asia-Eropa terlihat dalam struktur sosial, budaya, dan cara berdagangnya. Dimana mereka (orang Asia) masih bersifat otonom namun kemudahan akses yang diberikan para kapitalis membuat mereka menjadi pasar dan terbelenggu dalam kekangan tersebut.

Hal ini yang memberi kesadaran pada khalayak di masa kini bahwa kebebasan yang mereka miliki sebenarnya tidak mereka pilih sendiri tetapi mereka hanya mengikuti segala sesuatu yang ada. Bangsa ini akan terus menjadi perpanjangan label asing dan terus melupakan kristalisasi ideologi bangsa (Pancasila). Langkah awal untuk bersikap dan bertindak harus dimulai dari berpikir historis. Dengan hal itu, kita dapat menggunakan sejarah secara tepat dan tidak menyalahgunakannya untuk membenarkan sekaligus melegitimasi masa lalu untuk kepentingan masa kini. Karya van Leur memberi penjelasan akan peradaban Nusantara. Tulisan ini berupaya membahas kehidupan van Leur, pendekatan weberian dan historiografi Indonesiasentris, perdagangan dan embrio kapitalisme, Hinduisasi Nusantara, Islamisasi Nusantara, dan Oksidentalisme Nusantara.

\section{KEHIDUPAN JACOB CORNELIS VAN LEUR}

Van Leur menilai karyanya dengan label "tiada nilai selain sebuah kompilasi". Hal ini bukan hanya menunjukkan sikapnya yang begitu rendah hati tetapi juga mengindikasikan apa yang dia goreskan bukanlah suatu hal yang baru. Naisbitt (2006) berargumen bahwa tidak ada sesuatu yang baru dibawah matahari. Walaupun perubahan merupakan suatu keniscayaan tetapi perubahan itu hanya berputar dalam suatu yang konstan. Manusia hanya sekedar merevitalisasi nilai-nilai lama di masa kini saja. Begitu pula dengan maha karya van Leur. Dia begitu terinspirasi oleh pijar pikiran dari Max Weber. Oleh karena itu, wajar apabila dia menerapkan asumsi dasar teori Weber dalam penelitiannya. Dia mengetahui Max Weber ketika sedang menempuh studi doktoralnya di Universitas Leiden, Belanda. Dia begitu meneladani ilmuwan terkemuka saat itu, Cornelis van Vollenhoven. Menurut Kanumoyoso (2015:xi), cara berpikir van Leur sama halnya dengan cara berpikir van Vollenhoven ketika melihat hukum adat di Asia Tenggara. Van Vollenhoven adalah sosok ideal seorang ilmuwan yang mengabdikan diri untuk kemajuan keilmuan. Vollenhoven pula yang memperkenalkan pemikiran Weber pada van Leur. Menurut Fasseur (2010), van Vollenhoven telah mengakhiri kesan dualistik dalam perkembangan hukum di Hindia-Belanda. Dia melihat bahwa adat, dan bukan hukum Belanda, adalah kunci dalam mengelola koloni dengan baik. Kesan seperti inilah yang kemudian membuat van Leur juga melakukan hal yang serupa.

Dia menyelesaikan pendidikan tingginya di Jurusan Indologi. Di Universitas Leiden, dia memiliki banyak kesempatan untuk mengembangkan minatnya pada sejarah budaya, ekonomi, dan sosial Eropa, dan juga Asia. Dia menggunakan basis pengetahuannya untuk merenungkan hilangnya kota-kota seperti Milddelburg, Veere, dan Flushing yang berperan sebagai pusat-pusat perdagangan di masa lampau. Semasa dia menempuh pendidikannya, ideologi kolonial Belanda begitu mewarnai jiwa zaman saat itu. Dia melihat suatu kecenderungan bahwa koloni harus dipahami dari masyarakat koloni itu sendiri bukan sebagai masyarakat yang dipengaruhi oleh kuasa Barat. Oleh karena itu, cara pandangnya yang dianggap radikal, mengubah Eropasentris menjadi Indonesiasentris, harus dilihat sebagai "pengetahuan politis" bukan "pengetahuan murni" jika meminjam ungkapan Edward C. Said (2010). Van Leur tentunya terlibat pada kepentingan politis Belanda di Asia Tenggara terutama Jawa. Dengan kata lain, 
pengetahuan yang dia hasilkan cenderung dipakai oleh para pengambil kebijakan baik secara langsung maupun tidak langsung.

Pendidikan Indologi yang dia tekuni menjadi bekal saat dia menjalankan tugas pengabdian ke Hindia Belanda. Dia adalah seorang kandidat asisten pengawas di Tulungagung pada tahun 1936. Namun kemudian, pada tahun 1936 dia dipindahtugaskan ke kesekretariatan umum di kantor gubernur di Bogor. Dia mengemban amanat sebagai pegawai keuangan dan urusan-urusan ekonomi. Selain itu, disana dia tetap aktif dalam berkarya. Dia menjadi salah satu anggota sarjana dibawah bimbingan Prof. Logeman dalam mengeksplorasi sumbersumber VOC mengenai hukum konstitusional. Dia juga ikut serta dalam mendirikan Masyarakat Seni dan Ilmu Pengetahuan Batavia. Tidak lupa seperti kaum romantis, dia juga terus mengaji sejarah Indonesia (Wertheim, 1967:v).

Tidak banyak memang yang diketahui dari seorang Van Leur selain karyanya tersebut. Dia tidak banyak melihat dunia seperti halnya orang lain yang memiliki "kuota" hidup $\pm 3 / 4$ abad. Dia meninggal dalam usia yang relatif muda, 34 tahun, pada 1942. Dia gugur ketika menjalankan tugas sebagai pemecah kode di salah satu kapal perang Belanda dalam pertempuran menghadapi armada kapal Jepang di Laut Jawa (Kanumoyoso, 2015:xii). Akan tetapi, namanya akan selalu dikenang karena dia menulis sebuah karya. Setiap karya tulisnya akan selalu dikenang sepanjang masa oleh umat manusia. Karya tulisnya dihimpun dalam satu buku dan diterjemahkan dalam Bahasa Inggris atas inisiatif W.F. Wertheim, Guru Besar Sosiologi Universitas Amsterdam.

\section{PENDEKATAN WEBERIAN DAN HISTORIOGRAFI INDONESIASENTRIS}

Van Leur beberapa kali menekankan pentingnya penggunaan teori sosial-ekonomi Max Weber untuk melihat kenyataan historis. Dia memulai dengan memberikan cakupan kecenderungan permasalahan di awal abad XX, dalam: "tiga masalah dunia yang sedang melanda dunia adalah masalah negara, rakyat, dan ekonomi" (Heichelheim dalam van Leur, 2015:11). Relasi antara ketiganya telah membuat beberapa pemikir berupaya untuk memberikan redefinisi fundamental. Relasi tersebut bermuara pada perkembangan kapitalisme modern yang membuat dunia semakin mengglobal. Hal ini dilihat oleh berbagai pemikir sebagai perpanjangan tangan dari kapitalisme Barat di dunia Timur. Dengan keberadaan kapitalisme, kebebasan berusaha sekaligus kebebasan berpikir terlihat menjadi dominasi dari bangsa Barat. Hegel (2005:36) melihat dunia Timur sebagai bangsa yang tidak mengetahui kebebasan dan karena itu terikat pada objeknya. Mereka tersadar hanya ketika dipengaruhi oleh budaya Barat. Demikian pula Marx, disebut van Leur (2015:15), membagi sejarah dunia menjadi empat fase yakni fase Asia, klasik, feodal, dan kapitalis. Marx memberikan stigma pada orang Asia yang memiliki kelaliman birokrasi.

Namun pada kenyataannya abad pertengahan bukanlah abad yang mengglobal dan didominasi oleh Barat. Para sejarawan Barat cenderung melupakan fakta bahwa zaman pertengahan Bizantium-Islam memiliki energi yang dapat langsung mempengaruhi negerinegeri di Eropa. Selain itu, mereka memiliki kemajuan dan kematangan bentuk dalam peraturan bisnis, organisasi pedagang dan serikat pengrajin, pemerintahan kota, birokrasi dan administrasi negara, sistem mata uang, perbankan, urusan fiskal, organisasi militer dan angkatan laut, serta aturan dan hukum perniagaan. Sementara itu, abad pertengahan Barat hanya berkembang sebagian, bentuknya tidak matang serta kurang kekayaan dan kerumitan. Fakta ini menunjukkan ada sesuatu yang ganjil jika menyebut kapitalisme modern adalah keberpengaruhan dari peradaban Barat. Di setiap zaman dimanapun itu, kita pasti dapat menemukan bentuk-bentuk kapitalisme (van Leur, 2015:20).

Van Leur (2015:26) menyebut jika kita meminjam teori Weber maka kita akan mengetahui sistem sosial-ekonomi yang relevan pada seluruh wilayah. Dengan kata lain, teori Weber tidak disebutnya lebih mengedepankan pada pengaruh Barat pada suatu masyarakat 
namun malah melihat keberadaban dunia Timur. Weber melihat hal tersebut dalam logika sejarahnya yang menitikberatkan pada doktrin kemanusiaan. Menurut Weber (2002:315), masyarakat oriental dan oksidental memegang hak prerogatifnya masing-masing. Ketika kekuasan Romawi mengemuka begitu banyak manusia yang menjadi budak namun di Cina banyak orang terdidik yang humanis. Selama dua puluh abad, lapisan sosial di China lebih ditentukan oleh kualifikasi jabatan daripada kekayaan. Pada gilirannya, kualifikasi ini ditentukan oleh pendidikan, dan khususnya oleh ujian-ujian. China membuat pendidikan literer menjadi ukuran prestise sosial dalam bentuk yang paling ekslusif, jauh lebih eksklusif daripada di Eropa selama periode humanis, atau seperti yang telah dilakukan oleh Jerman. Oleh karena itu, tidak dapat untuk disebutkan masyarakat Barat mempengaruhi pemikiran masyarakat Timur. Tidak salah jika kemudian muncul pameo "tuntutlah ilmu sampai ke Negeri China" yang berkembang di masyarakat global.

Van Leur berupaya mengikuti apa yang dikerjakan oleh Weber. Dia melihat bahwa perspektif periodisasi Sejarah Eropa tidak dapat digunakan ketika mengamati perkembangan Sejarah India dan Cina. Van Leur, seperti halnya Weber dan van Vollenhoven, cenderung mengaji suatu koloni dari perspektif historis. Mereka melihat suatu objek kajian bukan dari pandangan luar (etik) tetapi lebih mendalami dari pandangan dalam (emik). Melihat suatu perkembangan masyarakat tertentu dari perspektif masyarakat itu sendiri. Periodisasi sejarah Barat melihat kategori sejarah dengan kuno, pertengahan, dan modern. Hal ini tidak bisa dipakai ketika melihat perkembangan Sejarah India.

Sejarah India tidak dapat dirangkai dengan periodisasi sejarah Eropa dari masa kuno, pertengahan, maupun modern karena tidak ada kekuatan ataupun pengaruh budaya yang disebarkan oleh Eropa Barat. Sejarah India tidak memiliki kesamaan pola dengan Sejarah Eropa. Hal ini terlihat jelas dari ketiadaan ekspansi Romawi ke India seperti yang jamak terjadi di Eropa daratan. Otonomi dan keterpisahan penaklukan orang-orang Arya di anak benua
India, kemunculan dan konsoloidasi kerajaankerajaan besar dan pembentukan sistem sosial, kerumitan sejarah sosial-ekonomi yang diboncengi gerakan keagamaan (van Leur, 2015:27-28).

Begitupula dengan sejarah Cina yang memiliki fakta unik keberlanjutan negara terpusat selama sekitar 2000 tahun di wilayah yang sama serta keberlanjutan tradisi dan peradaban tanpa adanya alur sejarah sosial-ekonomi yang berjalan segaris atau memiliki gambaran yang berbeda dengan kerumitan dunia Eropa. Namun demikian, perkembangan Jepang adalah perkecualian. Mereka mengimpor sistem pemerintahan Barat dengan sistem kapitalisme modern. Hal disebut terakhir telah memunculkan pendirian kapitalisme modern disana sekaligus representasi hegemoni kaum aristokrat. Van Leur (2015:37) memberikan penjelasan yang menarik mengenai kesamaan pola Sejarah Jepang dengan Dunia Kuno Mediterania, sebagai berikut:

“...dari abad XVII hingga XIX, Jepang
memperlihatkan proses: represi
memihak pada kekuatan sosial
bangsawan, pertumbuhan pedagang-
pedagang perkotaan dan pemegang
modal, penindasan di wilayah pedesaan
akibat tanggungan utang, migrasi untuk
pergi dari negeri tersebut, dan
pertumbuhan orang miskin serta
tunawisma... proses tersebut (kiranya
sama dengan apa yang) terdapat dalam
Mediterania Kuno: beban utang di
pedesaan, sistem riba dalam sistem
utang, terdapat pula bentuk perjuangan
kelas dunia kuno...”

Lebih lanjut, van Leur (2015:31) menyebut istilah Barat dan Timur sebagai gagasan yang kabur. Suatu ideologi telah membagi dunia menjadi dua, yakni Timur (oriental) dan Barat (oksidental). Hal ini yang menyebabkan pengabaian kekayaan, kompleksitas, dan bentukbentuk budaya dan kehidupan yang telah mencapai kematangan melalui jalur-jalur otonom. Barat merasa memiliki keberadaban yang melebihi Timur sehingga mereka berupaya untuk memberadabkan dunia Timur sesuai dengan nilainilai Barat. Ideologi ini disebut oleh Samuel 
Huntington (2012) sebagai universalisme bagi masyarakat Barat dan imperialisme bagi masyarakat Timur. Sejarah ekonomi (dan sosiologi) diperlukan untuk mengakhiri kebingungan tersebut. Selain itu, sejarah sosialekonomi juga berhadapan dengan permasalahan utamanya yakni "bagaimana kapitalisme modern muncul dan pasifikasi-nya ke dunia". Untuk melihat ideologi yang "memberadabkan" dan perkembangan kapitalisme modern dapat digambarkan dengan kategori sejarah dari masyarakat setempat serta bukan menerapkan kategori-kategori sejarah Eropa Barat (van Leur, 2015:39).

Akan tetapi, van Leur (2015:42) melihat bahwa seluruh teori ekonomi (yang mendukung penjelasan pendekatan sejarah ekonomi) nampak terasing dari kenyataan sejarah. Teori-teori ekonomi modern disebut sebagai hal yang universal ternyata tidak berguna ketika diterapkan pada kenyataan-kenyataan sejarah (tetapi sesuai dengan perjalanan Sejarah Barat). Reduksi terhadap tendensi-tendensi umum menyebabkan hilangnya keunikan dari setiap fenomena sejarah. Lebih lanjut, van Leur (2015:52) menjelaskan adanya kenyataan yang tidak terbantahkan. Penentuan harga dalam ekonomi desa di Indonesia atau perdagangan masyarakat lokal tidak sesuai dengan teori penentuan harga untuk produk-produk dari pertanian atau pertambangan Eropa. Teori tersebut padahal sangat berguna sebagai alat heuristik dalam metodologi sejarah.

Dengan kata lain, cara kerja teori adalah untuk menentukan data penting mana yang harus diambil dalam penelitian historis. Namun demikian, apa yang dikemukakan Van Leur perlu dikunjungi kembali. Teori yang kita gunakan dalam penelitian bukan dimaksudkan untuk pedoman pengambilan data tetapi sebagai alat analisis berdasarkan data empiris. Oleh karena itu, seorang peneliti berkewajiban memiliki kekayaan bekal teori ketika berhadapan dengan data yang ada. Ketika teori yang kita sesuaikan tidak dapat menjelaskan data yang ada maka teori tersebut perlu kita sesuaikan lagi.

Van Leur (2015:46-47) juga menyebut ilmu sejarah dengan bantuan teori ekonomi tidak lagi dimasukkan pada ilmu alam yang berupaya membuktikan suatu teori atau menyesuaikan hukum-hukum yang ada tetapi dimasukkan pada ilmu humaniora yang melihat keunikannya. Dia cenderung melihat bahwa ilmu sosial sama dengan ilmu humaniora ketika membedakannya dengan ilmu alam. Padahal, baik Kartodirdjo (1993) maupun Kuntowijoyo (2003) sepakat bahwa ilmu sejarah terlihat sebagai ilmu humaniora di satu kaki dan ilmu sosial di kaki yang lain. Hal ini berarti kita tidak bisa menyamakan antara ilmu humaniora dan ilmu sosial.

Cara pandang yang menekankan pada pandangan objek (emik) bukannya menekankan pada kehendak subjek menjadikan van Leur sebagai pendobrak dominasi elit dan membuka keunikan kehidupan massa. Wertheim menjadi salah satu orang yang terinspirasi. Wertheim (2009), dalam Karyanya "Elite versus Massa", memberikan penjelasan yang kritis pada keberadaan sosiologi yang disebutnya mengarah pada ketidaktahuan. Dia melihat kaum elit cenderung tidak ingin mengetahui atau mengetahui tetapi disimpan (untuk kebijakan tertentu) terkait dengan massa rakyat. Mereka (termasuk para sosiolog) lebih menonjolkan ragam hidup dari kehidupan kaum elit dan mengabaikan massa rakyat. Kaum elit juga seharusnya mulai membuka mata untuk memenuhi kebutuhan massa. Pendekatan yang digagas oleh Wertheim dapat dilihat sebagai suatu teorobosan dalam mengaji suatu fenomena.

Selain Wertheim, Kanumoyoso (2015:xiii) menyebut Glamann, Meilink-Roelofsz, dan Steensgard sebagai sejarawan yang terinspirasi oleh pemikiran van Leur. Namun, dia melupakan sosok murid Wertheim yang di kemudian hari disebut sebagai Bapak Sejarah Indonesia, Sartono Kartodirdjo. Beliau kiranya yang telah mewarisi pemaduan antara sejarah dan ilmu sosial serta pandangan emik (Indonesiasentris) dari van Leur melalui tangan Wertheim ketika menempuh studi doktoral di Amsterdam. Kartodirdjo (2001:13) menulis:

“...the works of Schrieke and van Leur shied away from the official colonial historiography adopted by Stapel with its Neerlando-centric point of view. In 
actual fact, the above authors followed by Wertheim can be regarded as precursors of the writing of Indonesian history from the inside..."

Perkembangan ilmu sejarah di Indonesia seringkali terbawa dalam arus perdebatan dikotomis antara nomotetis dan ideografis. Hal ini hadir sebagai konsekuensi logis hadirnya kategorisasi keilmuan antara ilmu alam dan ilmu kemanusiaan. Ilmu sejarah dianggap sebagai bagian dari ilmu kemanusiaan yang memiliki karakteristik seperti ideografis, keunikan, deskriptif-naratif, interpretatif, kualitatif, dan subjektif. Para sejarawan "dipaksa" untuk memperteguh posisi sejarah sebagai humaniora dalam ranah keilmuan. Hasilnya, karya sejarah berfokus pada hal yang khusus tanpa membuat suatu generalisasi.

Para sejarawan hanya berupaya untuk membuat lukisan atau gambaran kejadian dalam keunikan secara rinci tanpa diperbolehkan untuk menyusun penemuan atau pola-pola sebagai proyeksi ke masa depan. Seolah-olah sejarah lebih dekat pada cara kerja yang subjektif daripada ilmu sosial yang mengambang antara ilmu alam yang bersifat nomotetis-objektif dan ilmu kemanusiaan yang berkarakter ideografissubjektif. Hal yang mengambang inilah yang dijadikan sebagai suatu landasan bagi sejarawan dalam memadukan (raaproachment) Ilmu Sosial dan Sejarah. Kartodirdjo (1993:129) menjelaskan bahwa metodologi dan pendekatan ilmu sosial bagi sejarah akan meningkatkan kemampuan analitisnya; maka akan lebih tampil unsur-unsur dan dimensi-dimensinya, juga jaringan yang kompleks. Metodologi tersebut memberi harapan besar bagi perkembangan sejarah karena meningkatkan produktivitasnya.

Selain itu, dia getol mengampanyekan sejarah nasional sebagai proyek pembangunan identitas bangsa. Dengan kata lain, dia ingin untuk menyebarkan perspektif Indonesiasentris pada khalayak. Perspektif tersebut tertuang dalam penulisan sejarah nasional. Dalam penulisannya harus ditekankan pada aspek kebermanfaatannya sehingga memerlukan dukungan konsep dan teori ilmu sosial. Suatu peristiwa historis diulas dan dianalisis berdasarkan dukungan konsep dan teori tertentu. Penulisan ini akan memberikan inspirasi yang menginspirasi khalayak untuk: berpikir solutif, berpikir global, dan berpikir humanis (Kartodirdjo, 2001:17).

Walaupun gagasan Van Leur telah dikembangkan sedemikian rupa namun masih terdapat dua proyek yang jarang dikembangkan oleh sejarawan kini. Pertama, sejarah Indonesia dilihat sebagai seperangkat metodologis yang membutuhkan kerjasama para arkeolog, filolog, dan sejarawan. Kedua, sejarah Indonesia sebagai sejarah internasional karena berbagai kajian etnografis dan dokumen menunjukkan berbagai dominasi masyarakat dan ideologi dalam perkembangan masyarakat Indonesia (Van Leur, 2015:231). Hal yang disebut terakhir adalah yang kini disebut sebagai perspektif sejarah global. Sejarah global berupaya untuk melihat suatu peristiwa sebagai suatu konstruksi timbal balik antara lokal, nasional, dan internasional.

\section{PERDAGANGAN DAN EMBRIO KAPITALISME}

Van Leur, seperti yang diungkap dimuka, berupaya menggunakan teori Weber dalam memahami realitas sejarah. Dia berupaya memakai pendekatan sejarah sosial-ekonomi untuk melihat perubahan dan kesinambungan dari perjalanan manusia, sehingga tidak lagi membicarakan bangunan atas dan berfokus pada bangunan bawah yang membentuknya. Kita tidak akan menyoroti tentang keindahan arsitektur Akropolis namun organisasi pembangunnya yang terhubung dengan polis. Demikian pula, tidak akan menyoroti nilai peradaban orang-orang Cina yang terpelajar melainkan pentingnya hal tersebut sebagai ungkapan yang digunakan oleh birokrasi (Van Leur, 2015:59).

Jika Weber membahas mengenai India dan Cina, van Leur mencoba memahami Indonesia. Dia melihat orang Indonesia memiliki keberadaban yang otonom terpisah dari peradaban Barat. Pengaruh utama Barat adalah adanya sistem kapitalisme. Namun, sistem tersebut sesungguhnya dimiliki oleh semua masyarakat dimanapun berada. Jauh sebelumnya 
datangnya Barat, orang Indonesia telah mengembangkan sistem perdagangan yang memiliki pola yang sama dengan kapitalisme Eropa. Hal ini terlihat dari adanya komoditi dalam peradaban agraris sebagai faktor pendukung adanya perdagangan (Van Leur, 2015:67). Van Leur (2015:69) memberikan penjelasan:

“...Migrasi yang terjadi antara tiga benua
Asia, Afrika, dan Eropa beriringan
dengan terbukanya jalur atau lalu lintas
perdagangan pada masa prasejarah.
Dalam peradaban agraris, organisasi
sosial menawarkan penjelasan mengenai
kemungkinan serangkaian bentuk
perdagangan (jual beli, sewa, utang,
upah, pembagian panen) selain menjadi
petani, mereka juga mengembangkan
keahlian pedagang keliling yang
menjadikan hal tersebut sebagai
pekerjaan kedua..."

Malinowski dalam van Leur (2015:70-81) memberikan penjelasan bahwa masyarakat primitif telah mengembangkan perdagangan dengan sistem "potlach". Sistem "potlach" perdagangan (antarpulau) yang mengikat populasi masyarakatnya untuk saling menukarkan barang yang telah ditentukan oleh tradisi setempat. Poesponegoro (2008:410) memberi penjelasan menarik terkait perdagangan antarpulau yang dilakukan oleh masyarakat Nusantara pada masa perundagian tradisi palaeometalik, sebagai berikut:

“...perdagangan dilakukan antar-pulau di Indonesia dan antara kepulauan Indonesia dengan Daratan Asia Tenggara. Perahu bercadik memainkan peran yang besar dalam hubunganhubungan perdagangan ini. Perdagangan dilakukan dengan cara tukar-menukar barang yang diperlukan oleh kedua belah pihak...perdagangan dengan Daratan Asia Tenggara rupa-rupanya telah berkembang dengan pesat dan barangbarang yang diperdagangkan terutama rempah-rempah, jenis-jenis kayu, dan hasil bumi lain..."

Transaksi "potlach" adalah fenomena yang dapat ditemukan di seluruh dunia dan di Indonesia sekaligus menjadi permulaan perkembangan kapitalisme dunia, dari sistem barter menuju perdagangan dunia. Perdagangan dalam peradaban agraris menjadi basis dari perkembangan kapitalisme. Ketika modal kemudian berkembang dalam sistem perbankan dan kota-kota pelabuhan lahir maka perdaganan dunia akan terlaksana. Perdagangan dunia sangat ditentukan oleh pemilik uang yang kaya raya dan pedagang keliling. Dalam perdagangan internasional, kaum bangsawan dan aristokrat bersifat pasif sehingga dapat dikatakan bahwa mereka adalah pemilik modalnya dan mereka berinvestasi dalam commenda (kontrak) dan pinjaman dengan jaminan kapal atau isi kapal. Mereka yang aktif adalah para pedagang kerajinan yang melakukan perjalanan dengan uang commenda atau barang dagangan commenda. Selain mereka, juga ada pedagang kerajinan yang merdeka dan pedagang keliling yang mengembara (Van Leur, 2015:92-93).

Terlepas dari karakter kapitalisme yang merasuk dalam kehidupan sosial-ekonomi di Nusantara, masyarakat telah memiliki berbagai kearifan lokal sebelum kedatangan bangsa asing. JLA Brandes dalam Munandar (TT) mengidentifikasi 10 kepandaian yang meluas di awal tarikh Masehi yaitu (1) telah dapat membuat figur boneka, (2) mengembangkan seni hias ornamen (3) mengenal pengecoran logam, (4) melaksanakan perdagangan barter, (4) mengenal instrumen musik, (6) memahami astronomi, (7) menguasai teknik navigasi dan pelayaran, (8) menggunakan tradisi lisan dalam menyampaikan pengetahuan, (9) menguasai teknik irigasi, dan (10) telah mengenal tata masyarakat yang teratur.

\section{HINDUISASI NUSANTARA}

Seringkali istilah Hindu (Hinduisasi) dan India (Indianisasi) dipakai secara bergantian untuk menyebut pengaruh budaya dari masyarakat anak benua Asia. Suwarno (2012:2) menjelaskan bahwa India berasal dari kata "Indoi" yang berarti bangsa yang mendiami daerah atau aliran sungai Indus atau ada pula yang menyebut mereka sebagai Hindustan yang berarti negeri Sungai Sindhu atau Indus. Oleh karena itu, 
apabila kita menggunakan istilah Hinduisasi atau Indianisasi secara bergantian bukanlah suatu hal yang prinsipil untuk diulas. Akan tetapi siapa yang membawa Hindu ke Nusantara menjadi fokus disini.

Van Leur (2015:135-7) menyimpulkan bahwa masyarakat Indonesia bukanlah masyarakat primitif, yang bodoh, ketika pengaruh asing masuk mulai Hindu, Islam, dan Barat. Mereka memiliki berbagai bentuk tatanan pemerintahan, hukum, sosial, dan sosial-ekonomi sesuai dengan keadaan setempat. Walaupun mereka selalu ditundukkan oleh ujian kekuatan yang paling berat mereka membuktikan bahwa mereka memiliki kekuatan resistensi yang kuat. Salah satu contoh dari adanya resistensi yang mencerminkan karakteristik bangsa Indonesia adalah ketika masyarakat Jawa dikuasai baik secara politik, sosial, dan budaya oleh Inggris di bawah Sir Thomas Stamford Raffles. Namun, masyarakat tetap memperlihatkan resistensinya dalam bentuk simbol-simbol budaya. Simbol resistensi tersebut direpresentasikan dalam permainan rampogan macan.

Rampogan macan berasal dari masa pemerintahan Amangkurat II Kartasura. Pertunjukan sakral ini akan diselenggarakan ketika Keraton menerima tamu agung seperti para Gubernur Jenderal serta Raffles (Soeratman, 1989:161-2). Acara ini mungkin dapat dilihat sebagai pertunjukan simbolis yang sama mengenai kekuatan sebuah negara yang teratur melawan kekacauan yang liar (Reid, 2011:216). Pertarungan sima-maesa (harimau melawan kerbau) sering dilekatkan dengan simbolisme harimau merepresentasikan orang Eropa (Belanda atau Inggris) dan kerbau melambangkan Jawa (Kumar, 2008:50). Hannigan (2015:299) berasumsi bahwa John Crawfurd telah memberitahu Raffles terkait dengan simbolisme pertarungan kerbau dan macan. Raffles (2014:241) berpendapat bahwa "dalam pertunjukan ini (rampogan macan), orang Jawa terbiasa untuk membandingkan kerbau dengan orang Jawa dan macan untuk orang Eropa. Dari sini bisa dibayangkan keinginan mereka untuk memenangkan kerbaunya".
Selain itu, Van Leur (2015:136-7) juga melihat bahwa masyarakat Nusantara memiliki pola berpikir yang asimilatif. Hal disebutkannya dalam:

“...Meski bentuk-bentuk kebudayaan asing yang berbeda dan beragam agama dunia yang berbeda telah secara silih berganti memengaruhi Indonesia, pandangan umum yang berlaku ialah bahwa pengaruh tersebut adalah lemah, kendati pengaruh-pengaruh tersebut bercokol di Indonesia selama berabadabad. Pengaruh-pengaruh tersebut tidak secara mendasar mengubah terhadap tatanan politik dan sosial. Kilau agama-agama dunia dan bentuk-bentuk kebudayaan asing hanyalah serpihan yang tipis dan kecil; di sisi lain, kebudayaan lokal pribumi tetap hidup, dengan beberapa tahapa yang muncul, sesuai dengan tingkat kebudayaan yang ada. Sihir dan kepercayaan terhadap roh-roh tetap bertahan meski di bawah pengaruh Hindu dan Islam; masyarakat Indonesia tidak memberikan jalan bagi diterapkannya hukum keilmuan Hindu dan Islam. lebih lanjut, kelompokkelompok yang menjadi perwakilan yang sadar dari kebudayaan asing dan agama-agama dunia selalu kecil dan terbatas..." (van Leur, 2015:136-7)

Pola berpikir asimilatif diatas dapat kita jadikan jalan untuk melihat alasan sekaligus siapa pembawa Hindu di Nusantara. Vlekke (2008:25) tidak memberikan kejelasan yang gamblang bagaimana proses Hinduisasi di Nusantara. Dia memberikan keterangan bahwa tesis penaklukan dengan kekuatan senjata tidak berdasarkan data yang ada. Hal ini diperkuat dengan ketiadaan koloni-koloni India di Indonesia. Dia kemudian juga menolak asumsi yang mengungkap penyebaran Hindu oleh para pelaut dan pedagang. Akhirnya dia melihat praktek agama di India Selatan sama seperti praktek keagamaan di Nusantara. Argumen diatas sebenarnya dapat kita jelaskan apabila memahami teori brahmana Van Leur, dengan sedikit mengabaikan teori arus balik F.D.K. Bosch. 
Van Leur (2015:138-9) melihat Hinduisasi yang terjadi di Nusantara sama halnya seperti yang terjadi ketika bangsa di India Utara (bangsa Arya) melakukan Hinduisasi ke India Selatan (bangsa Dravida). Dia melihat bahwa pendeta brahmana adalah aktor utama proses Hinduisasi tersebut. "misi brahmana" bukanlah penyebaran doktrin keselamatan melainkan penundukan dan pengaturan ritual dan birokrasi wilayah-wilayah baru. Dimanapun proses Indianisasi terjadi, organisasi agama selalu diiringi oleh organisasi sosial (pembagian kasta, legitimasi kelompok yang berkuasa dan jaminan supremasi kaum Brahmana). Organisasi sosial yang ditawarkan Hinduisme tersebut sangat menarik kaum aristokrat Nusantara dalam melanggengkan kekuasaannya di Nusantara.

Hubungan antara India Utara dengan Indonesia sangat kental. Dengan adanya jalur pelayaran, para aristokrat kemudian mengumpulkan para Brahmana di istana mereka (Van Leur, 2015:141). Para Brahmana yang kemudian banyak menjadi penasehat kerajaan. Mereka kemudian yang menata dan merestui setiap kebijakan kerajaan yang dikeluarkan, seperti halnya ketika Ken Angrok diabhiseka menjadi sang Śri Ranggah Rajasa Sang Amurwabhumi oleh para makudur (brahmana) ketika ingin menggulingkan Kertajaya yang ingin disembah oleh para brahmana.

Wajar apabila kemudian Van Leur begitu mengritisi teori ksatria atau teori waisya. Perdagangan dan pedagang memang dianggap sebagai penyebar kebudayaan Hindu. Namun jelas bahwa perdagangan tersebut tidak ditentukan secara jelas baik oleh N.J. Krom (teori waisya) maupun C.C. Berg (teori ksatria). Jika hal itu dilakukan, maka para pedagang tidak mungkin digambarkan sebagai pihak yang memainkan peranan dalam penyebaran tersebut. Mayoritas para pedagang adalah orang dari kelompok sosial yang rendah bahkan terdapat orang asing dari berbagai belahan negara lain (Van Leur, 2015:141).

\section{ISLAMISASI NUSANTARA}

Tesis Van Leur terkait keberadaban masyarakat Nusantara sebelum adanya kedatangan budaya asing diuji lagi. Namun kita akan melihat bagaimana masyarakat Nusantara terus berpikir asimilatif terhadap budaya asing yang masuk. Islam masuk dan berkembang dengan jalan damai. Hal ini dapat terjadi karena kaum muslimin yang menyampaikan ayat pada orang lain tidak memaksakan kehendak mereka. Menurut Riklefs (2005:27), terdapat setidaknya dua proses islamisasi yang mungkin terjadi. Pertama, penduduk pribumi mengalami kontak dengan agama Islam dan kemudian menganutnya. Proses kedua, orang-orang asing Asia yang telah beragama Islam tinggal secara tetap di Jawa misalnya, kemudian menikah dengan orang lokal dan mengikuti gaya hidup lokal sehingga mereka sudah menjadi orang Jawa.

Van Leur (2015:169) melihat hal yang serupa. Dia melihat bahwa setiap pedagang muslim yang berdagang ke Nusantara memiliki tugas sebagai seorang mubalig. Ketika mereka kontak dengan penduduk lokal, banyak yang tertarik karena Islam dianggap dapat membawa mereka pada keselamatan dunia dan akhirat. Oleh karena wajar apabila para pedagang dianggap sebagai aktor utama dalam menjalankan Islamisasi di Nusantara. Hinduisme tentu sangat berkebalikan dengan Islam. Hindu tidak memiliki misi profetik dan para penganutnya memiliki karisma yang magis dan eksluksif, sebuah karisma yang dipaksakan oleh ritual, pembagian masyarakat secara turun-temurun berdasar pada sistem kasta. Oleh karena itu, Hindu tidak pernah mengikuti jalur perdagangan dalam artian bahwa para pedagang merupakan misionarisnya. Artinya tugas misionaris hanya dapat dipenuhi oleh kaum brahmana saja.

Islam bukanlah sesuatu yang normatif tetapi lebih bersifat kontekstual. Islam sebagai ajaran normatif berasal dari Tuhan diakomodasikan ke dalam kebudayaan setempat sehingga setiap muslim tidak akan kehilangan identitasnya (Rahmat, 2003:xx). Bagi Baso (2003:214), cenderung mengikuti nasehat Sunan Kalijaga, "kalau ingin menjadi islam yang baik di 
tanah Jawa ini, jadilah Islam yang menjawa", ketika Islam mengapresiasi tarekat-tarekat agama lokal, mereka memberikan semangat kedinamisan dalam berdialog dengan budaya luar. Hal ini tentu berbeda dengan apa yang dilakukan oleh kaum revivalis, wahabi misalnya. Islam yang mereka bawa banyak ditolak. Hal ini karena mereka datang dengan larangan pada tarekat agama lokal. Muncullah berbagai resistensi pada Islam sehingga fatwa Islam tidak lagi menjadi populer.

Marsden (2008:263-4), seorang orientalis dari Skotlandia, memberikan ilustrasi yang menarik terkait Islamisasi di Masyarakat Rejang (suku bangsa tertua di Sumatera). Dia menulis:

“...Banyak orang yang menyebarkan agama Islam bukanlah orang yang murni Islam. Mereka bahkan tidak mengerti apa yang mereka lakukan. Seorang Melayu Islam bertanya pada orang desa, "mengapa kau memberikan sesembahan kepada makam nenek moyangmu?" si orang desa balik bertanya "atas dasar apa kau yakin bahwa Allah dan Muhammad akan membantumu?" apa kau tahu, "jawab si Melayu, "bahwa itu ditulis di kitab? Apa kau tak pernah membaca Al Qur'an?" orang Melayu tersebut akhirnya mengalah pada argumen ini karena dia lebih sedikit pengetahuannya..."

Orang Melayu Islam tersebut cenderung mengikuti internalisasi Peter L. Berger dan Thomas Luckman (1990). Akan tetapi mungkin mereka lupa menambahkan legitimasi imitatif. Hal ini disebabkan orang Melayu tersebut terpengaruh oleh Islam bukan dengan panggilan hati (legitimasi kognitif) atau paksaan (legitimasi normatif). Apabila dia terpaksa maka dia akan mengetahui pengetahuan Islam tetapi dia tidak memiliki banyak pengetahuan mengenai keislaman. Pengetahuan masyarakat pada tradisinya masih sangat kental seperti yang tergambar dari ungkapan orang desa tersebut. Terlihat bahwa disini masyarakat Nusantara belum bisa melepaskan tradisinya begitu saja. Bahkan, Marsden (2008:265\&275) menilai orang Sumatera begitu menghargai makam nenek moyang bagaikan hidup mereka sendiri. Di Lampung, dia mengamati sebagian besar dusun memiliki masjid tetapi kepercayaan pada takhayul tidak seluruhnya hilang. Hal itu mendorong mereka untuk mengeramatkan kuburan-kuburan nenek moyang.

Walaupun Islam berkembang dan menyebar melalui saluran perdagangan internasional Asia tetapi ternyata Islam tidak memberikan perkembangan ekonomis yang berarti bagi Indonesia. Islamisasi Indonesia ditentukan secara bertahap oleh situasi dan motif politik (Van Leur, 2015:163-5). Kehadiran Islam diterima dengan baik oleh masyarakat kelas menengah-bawah pada mulanya. Hal ini disebabkan karena kegiatan dakwah Islam langsung diarahkan kepada rakyat (Van Leur, 2015:170). Mereka sangat meyakini bahwa kehadiran Islam akan mampu mengeluarkan mereka dari penindasan raja-raja feodal selama ini. Islam mengajarkan prinsip egalitarianisme. Ajaran inilah yang mampu menyedot perhatian khalayak. Patut diingat bahwa Islam datang bukan dalam bentuk yang murni. Menurut Magnis-Suseno (1984:32), kedatangan Islam ke Jawa bukan dipelopori oleh kaum Wahab tetapi para Sufis Gujarat. Proses Islamisasi berlangsung tanpa adanya goncangan-goncangan besar dan dapat diterima dan diintegrasikan dalam pola budaya, sosial, dan politik yang sudah ada. Menariknya para wali yang dianggap sebagai penyebar pertama Islam di Jawa menggunakan tradisi masyarakat setempat seperti wayang untuk berdakwah.

Riklefs (2013:30) menuturkan bahwa masih lazim terjadi pergolakan batin antara menjadi Muslim atau menjadi Jawa pada masa itu. Islamisasi memperlihatkan pola yang diwarnai perbedaan dan kepelikan sejak periode awal. Ada dua proses yang nampaknya terjadi secara bersamaan: kaum Muslim asing menetap di suatu tempat dan menjadi orang Jawa sementara masyarakat lokal memeluk Islam dan menjadi Muslim. Selain itu, pergolakan batin tidak hanya yang mendukung Islam atau Jawa tetapi juga semakin besarnya pengaruh bangsa barat. Para penguasa lokal bingung untuk memilih antara menjadi Muslim dan menjadi 
Kristen di tengah pengaruh besar kedua agama tersebut. Menurut Vlekke (2008:108-9), raja-raja dihadapkan pada pilihan untuk bersekutu dengan Portugis atau bekerjasama dengan Johor atau Demak sekaligus mereka memilih Kristen atau Islam. Menariknya, mereka tidak terpengaruh oleh isi kedua dogma dari dua ajaran tersebut tetapi adalah mana yang paling berfaedah bagi mereka.

Salah satu penguasa lokal yang kemudian menggunakan tradisi Islam dan Jawa dalam menghadapi kekuatan Barat adalah Sultan Agung. Dia berupaya untuk mempertemukan dan mendamaikan keraton dengan tradisi-tradisi Islami. Sultan Agung tidak lantas memutus hubungan mistisnya dengan penguasa rohani tertinggi yang diyakini oleh masyarakat asli Jawa Tengah (Ratu Kidul) tetapi dia juga mengambil langkah tegas untuk menjadikan Mataram menjadi kerajaan yang lebih Islam. Dia kemudian banyak berziarah ke makam Sunan Bayat, tokoh yang dianggap penyebar pertama Islam di wilayah Mataram. Selain itu dia juga menikahkan salah satu putrinya dengan pangeran dari Surabaya. Dari pangeran inilah kemudian Sultan Agung diberitahu tentang keberadaan wali yang masih menjadi moyang dari sang pangeran. Menariknya Sultan Agung memperkenalkan kitab Usulbiyah pada khalayak dimana dalam Kitab tersebut Nabi Muhammad digambarkan mengenakan mahkota emas dari Majapahit. Gambaran tersebut mempersatukan dua simbol yakni Islam dan Jawa (Riklefs, 2013:32-3).

Islam Jawa terlihat longgar jika dibandingkan dengan Islam di tempat lain. Menurut Crawfurd (1820:47), dari semua pengikut Muhammad, orang Jawa adalah orang yang paling longgar dalam hal prinsip maupun praktek agama mereka. Mereka mampu untuk menyesuaikan berbagai ajaran Islam dengan tradisi-tradisi peribadatan sebelumnya. Hal ini juga telah diungkap oleh Stockdale dan Thorn. Stockdale (2010:197) berargumen bahwa Agama orang Jawa adalah Islam yang bercampur dengan berbagai takhayul yang didapat dari keyakinan nenek moyang mereka. Masyarakat pedalaman bahkan tidak memiliki gagasan abstrak mengenai agama dan memang tidak akan bisa timbul dari penalaran mereka yang masih mentah. Thorn (2004:222) berpendapat bahwa agama yang dianut oleh orang Jawa adalah ajaran Nabi Muhammad, namun telah bercampur dengan banyak takhayul. Hal tersebut memperlihatkan watak khas dari orang Jawa yang mampu bergaul dengan baik dalam putaran globalisasi. Orang Jawa seringkali menyapa orang asing dengan panggilan ki-sanak atau saderek yang keduanya berarti "kerabat". Mereka selalu berpikir bahwa kerugian materi tidak terlalu penting bagi mereka tetapi yang terpenting adalah mendapatkan kerabat. Hal ini menunjukkan bahwa orang Jawa dalam berdagang seringkali tidak mencari untung. Mereka mengganggap kehilangan untung dianggap hal yang lumrah (layak) apabila bisa mendapat kerabat sebagai gantinya (Moertono, 1985:18).

Karakteristik tersebut dipengaruhi oleh kaidah dasar kehidupan masyarakat Jawa yakni keselarasan sosial. Menurut Magnis-Suseno (1984:38), masyarakat Jawa memiliki dua kaidah yang paling menentukan pola pergaulan masyarakat. Kaidah pertama merujuk pada setiap situasi manusia hendaknya bersikap fungsional agar tidak menimbulkan konflik. Kaidah kedua menuntut agar manusia dalam berbicara dan membawa diri selalu menunjukkan sikap hormat terhadap orang lain sesuai dengan derajat dan kedudukannya. Kaidah pertama disebut sebagai prinsip kerukunan dan kedua disebut prinsip hormat. Kedua prinsip tersebut merupakan kerangka normatif yang menentukan bentukbentuk konkret semua interaksi.

Terlihat dengan jelas bahwa karakteristik orang Jawa cenderung bersikap moderat serta mengutamakan harmonisasi kehidupan. Budaya Jawa bukanlah budaya yang statis dan terisolasi tetapi orang Jawa berpikir secara terbuka pada dunia yang terus berubah. Walaupun pengaruh asing terus masuk ke Jawa tetapi orang Jawa masih mampu mempertahankan tradisinya bahkan juga menyerang budaya asing tersebut. Magnis-Suseno (1984:1) mengutarakan bahwa ketika Hindu-Budha masuk ke tanah Jawa, agama baru yang bercorak religius-mistik tersebut sesuai dengan budaya Jawa Pra-Hindu yang animistik dan magis. Demikian pula ketika Islam datang 
dengan nafas bercorak monoteisme bertemu dengan budaya animistik magis menjadi Islam Nusantara (Arif, 2015:59). Van Leur (2015:172) sampai pada kesimpulan bahwa Islam tidak membawa peradaban yang lebih tinggi sebaliknya kebudayaan Hindu terus membumi. Bahwa banyak sekali tradisi Hindu-Indonesia yang tetap dipertahankan seperti halnya struktur kerajaan yang patrimonial pada saat Islamisasi berjalan dengan sempurna.

\section{OKSIDENTALISASI NUSANTARA}

Oksidental adalah lawan kata dari oriental. Jika oriental digunakan untuk menyebut masyarakat Timur maka oksidental digunakan untuk melihat dunia Barat dan oksidentalisasi dipahami sebagai pengaruh Barat. Asia mulai menerima kedatangan Bangsa Barat adalah ketika Portugis mulai melakukan ekspedisi kesana hingga puncaknya ketika menguasai Malaka serta Sunda Kelapa. Menurut van Leur (2015:174), rezim kolonial Portugal adalah sebuah rezim yang dibangun oleh dan di atas perang, pemaksaan, dan kekerasan, tidak mengalami tingkat kemajuan yang lebih tinggi secara ekonomi dalam konteks perdagangan Asia.

Rezim kolonial Portugal tidak memperkenalkan unsur ekonomi baru ke dalam perdagangan Asia Tenggara. Sistem dominasi politik dan ekonomi-monopoli, eksploitasi finansial, fiskalisasi pemerintahan-semuanya berasal dari zaman kekhalifahan dan Bizantium, dan kemudian sistem itu diadopsi oleh Portugal. Kekuatan politis Portugal memungkinkan berlakunya bentuk-bentuk itu di Asia. Superioritas militer merupakan satu-satunya faktor yang dibawa Portugal ke Asia sebagai suatu hal yang baru dan merupakan unsur Eropa (van Leur, 2015:175).

Portugal telah menganggu pelayaran dan perdagangan Asia. Mereka melakukan perdagangan dari India menuju Cina dan Jepang melalui Malaka, dan mengangkut rempahrempah dari Indonesia serta memainkan peranan dalam perdagangan tekstil India. Semuanya itu merupakan pelayaran monopoli kerajaan, yang dilengkapi dengan jumlah pelayaran yang dilakoni oleh pada saudagar-petualang kebangsaan Portugal (van Leur, 2015:178). Malaka menempati posisi yang strategis di Asia Tenggara. Malaka dilukiskan oleh Tome Pires dalam Poesponegoro (2008:15), "tidak ada pusat perdagangan yang lebih besar daripada Malaka...komoditas dari seluruh dunia Timur disini...”.

Setelah menguasai Malaka, Portugis juga mengirim ekspedisi ke Sunda Kelapa (pusat lada) dan Maluku (pusat cengkeh). Walaupun gagal total di Sunda Kelapa, mereka dapat menjalin persahabatan dan perjanjian kerjasama dengan Kesultanan Ternate. Disana Portugis diijinkan untuk membangun benteng dan melakukan monopoli cengkeh (Tjandrasasmita, 2009:65). Hak untuk mendahului atau dikenal sebagai monopoli bukanlah hal yang diperkenalkan oleh orang Eropa. Penguasa Aceh telah memperkenalkan monopoli merica dari pelabuhan-pelabuhan di pesisir barat Sumatera yang berada di bawah kekuasaannya, menginvestasikan uangnya, dan mendorong merica untuk dijual di pasar sebelum merica dari tempat lain didatangkan (van Leur, 2015:200).

Hal lain yang membuktikan kemajuan Asia dalam sistem kapitalisme terlihat dari penggunaan uang sebagai alat tukar suatu barang serta yang tidak boleh dilupakan mereka juga telah mengenal standardisasi nilai mata uang tertentu dengan mata uang lainnya. Van Leur (2015:206) menjelaskan:

“...Di Jawa dan juga di pelabuhanpelabuhan yang menjadi pusat perdagangan orang-orang Jawa, telah beredar uang tunai Cina yang terbuat dari timbel, yang ribuan diantaranya diikat menggunakan tali yang diselipkan di lubang yang terletak di tengah-tengah, dihitung sebagai 1 dollar spanyol. Selain itu juga ada uang Portugal dan Spanyol, uang dagang orang-orang Cina yang berupa perak batangan, larrin Persia, perak batangan kecil yang bentuknya menyerupai tapal kuda. Di Aceh orangorang menggunakan tael emas, di pesisir Barat Sumatera perdagangan utamanya terjadi dalam bentuk berter langsung berdasarkan kalkulasi uang dan uang 
dagang; di Sumbawa emas dan perak berfungsi sebagai uang; di Bima pertukaran barang dilakukan dengan batu kecil; di Jambi merica digunakan sebagai kembalian..."

Peradaban dalam sistem ekonomi inilah yang kiranya juga menginspirasi Raffles dalam kebijakan moneternya. Raffles bukanlah orang yang memperkenalkan ekonomi uang seperti yang dipahami khalayak umum. Bahkan pada masa Raffles beragam mata uang digunakan dalam perdagangan dan dia segera melakukan persamaan nilai mata uang tertentu pada mata uang Inggris seperti dollar Spanyol sama dengan lima shillings Inggris, dan rupee untuk separuh crown. Dalam mata uang lokal Jawa, sepuluh duit tembaga sama dengan wang (sebuah mata uang koin perak kecil), dan dua belas wang sama dengan satu rupee (Raffles, 2014:901).

Belajar dari sejarah tentu saja seharusnya membuat kita lebih bijaksana. Masyarakat Nusantara tidak gagap dan tidak merasa inferior dengan adanya kebudayaan baru. Mereka berpikir secara asimilatif, mengambil apa yang baik dari budaya asing yang masuk tanpa mengabaikan tradisi luhur yang ada. Ironis sekali jika masyarakat di masa kini tidak pernah menengok ke belakang. Matanya tertutup seperti kuda delman yang terus berlari ke depan. Masyarakat yang meminjam cara pandang Barat dalam melihat segala sesuatu ibarat anak kecil yang merasa dirinya telah dewasa. Dia merasa benar tetapi kebenarannya berputar di tempat. Mereka seperti tidak memiliki pedoman hidup untuk mengisi "kemerdekaan".

Van Peursen (1988) menjelaskan bagaimana strategi budaya yang harus digunakan pada masyarakat yang memiliki sikap berpikir asimilatif diatas. Hal ini dilakukan agar setiap generasi penerus tahu bagaimana cara mereka bersikap dan bertindak di masyarakat. Dengan kata lain mereka belajar tentang bagaimana memahami norma dan nilai yang ada dalam masyarakat. Mereka mengembangkan sikap terbuka (transendensi) pada budaya asing yang dianggap baik bagi perkembangan budayanya dan sikap tertutup (imanensi) untuk mempertahankan budaya lokal apa yang baik dalam menghadapi berbagai tantangan di masyarakat.

\section{PENUTUP}

Van Leur akan dikenang sebagai peretas penulisan sejarah dari dalam sekaligus menekankan pada otonomi masyarakat Indonesia. Hal ini yang kemudian menjadi embrio dari pendekatan sejarah nasional (perspektif Indonesiasentris). Sejarawan hanya akan menuliskan keunikannya. Akan tetapi, betapapun sejarawan Belanda mencoba menggunakan pandangan asiasentris-nya, dia tidak akan pernah bisa keluar dari masa lalunya dan budayanya (Wertheim, 1963). Begitupula dengan van Leur yang tidak bisa dikatakan pandangannya murni untuk pengembangan ilmu pengetahuan. Apa yang dia hasilkan tentu saja juga akan dimanfaatkan oleh penguasa. Namun demikian, apa yang ditulis oleh van Leur (dalam karyanya) membuat pukulan telak bagi orang Asia pada umumnya dan orang Indonesia pada khususnya. Masa lalu mereka ditulis oleh orang asing. Jika hal ini terus berlanjut akan menimbulkan malapetaka. Carey (2014:5) menjelaskan bahwa:

“...90 persen karya tulis ilmiah tentang Indonesia yang dipublikasikan di luar negeri justru disusun oleh mereka yang tinggal di luar Indonesia, yang sebagian besar tentunya adalah orang asing atau orang Indonesia yang sudah lama bermukim di luar negeri dan menjadi WNA. Jika angka ini benar, maka Indonesia merupakan salah satu negara di dunia yang paling kurang efektif menjelaskan dirinya sendiri kepada dunia luar. Situasi semacam itu tidak baik untuk Indonesia di masa mendatang...Indonesia akan menjadi sebuah kapal yang berlayar tanpa kompas..."

Mereka bingung sekaligus gagap ketika melihat realitas dewasa ini. Kita tidak bisa mengubah keadaan saat ini. Namun setidaknya kita dapat membuat sebuah arus balik agar generasi di masa depan tidak gagap dan kaget dalam menghadapi tantangan zaman yang akan mereka temui. 


\section{DAFTAR RUJUKAN}

Arif, S. 2015. "NU dan Islam Nusantara". A. Ubaid \& M. Bakir (Eds). 2015. Nasionalisme dan Islam Nusantara. Jakarta: Kompas

Baso, A. 2003. "Islam dan Dialog Peradaban". M. Imdadun Rahmat (Ed). 2003. Islam Pribumi: Mendialogkan Agama Membaca Realitas. Jakarta: Erlangga

Berger, P.L. \& T. Luckman. 1990. Tafsir Sosial atas Kenyataan: Risalah tentang Sosiologi Pengetahuan. Jakarta: LP3ES

Carey, P. 2014. Penggunaan dan Penyalahgunaan Sejarah: Pandangan Seorang Sejarawan Inggris tentang Indonesia. Kuliah Perdana Adjunct Profesor di Fakultas Ilmu Budaya Universitas Indonesia ( FIB -UI), pada tanggal 1 Desember 2014

Crawfurd, J. 1820. History of Indian Archipelago: Containing an Account of the Manners, Arts, Languages, Religions, Institutions, and Commerce of Its Habitants Vol.I. Edinburgh: Archibal Constable and Co. Edinburgh

Fasseur, C. 2010. "Dilema Zaman Kolonial: van Vollenhoven dan Perseteruan antara Hukum Adat dan Hukum Barat di Indonesia”. J.S. Davidson (Eds). 2010. Adat dalam Politik Indonesia. Jakarta: KITLV-YOI

Hannigan, T. 2015. Raffles dan Invansi Inggris ke Jawa. Jakarta: KPG

Hegel, G.W.F. 2005. Nalar dalam Sejarah. Jakarta: Teraju

Huntington, S. 2012. Benturan Antar Peradaban dan Masa Depan Politik Dunia. Jakarta: Qalam

Kanumoyoso, B. 2015. "Van Leur dan Dunia Perdagangan Asia Tenggara". Dalam J.C. Van Leur 2015.
Perdagangan dan Masyarakat Indonesia: Esai-Esai tentang Sejarah Sosial dan Ekonomi Asia. Yogyakarta: Ombak

Kartodirdjo, S. 1993. Pendekatan Ilmu Sosial dalam Metodologi Sejarah. Jakarta: Gramedia Pustaka Utama

Kartodirdjo, S. 2001. Indonesian Historiography. Yogyakarta: Kanisius

Kumar, A. 2008. Prajurit Perempuan Jawa: Kesaksian Ihwal Istana dan Politik Jawa Akhir Abad ke-18. Jakarta: Komunitas Bambu

Kuntowijoyo. 2003. Metodologi Sejarah. Yogyakarta: Tiara Wacana

Magnis-Suseno, F. 1984. Etika Jawa: Sebuah Analisa Falsafati tentang Kebijaksanaan Hidup Jawa. Jakarta: Gramedia

Marsden, W. 2008. Sejarah Sumatra. Depok: Komunitas Bambu

Moertono, S. 1985. Negara dan Usaha BinaNegara di Jawa Masa Lampau. Jakarta: Yayasan Obor Indonesia

Munandar, A.A. TT. Awal Perkembangan Kebudayaan di Kawasan Asia Tenggara. Artikel tidak Dipublikasikan. Depok: FIB-UI

Naisbitt, J. 2006. Mind Set!: Eleven Ways to Change the Way You See--and Create-the Future. New York: Harper Collins Publisher

Poesponegoro, M.D. 2008. Sejarah Indonesia Indonesia I: Zaman Prasejarah di Indonesia. Jakarta: Balai Pustaka

Poesponegoro, M.D. 2008. Sejarah Nasional Indonesia IV: Kemunculan Penjajahan di Indonesia. Jakarta: Balai Pustaka

Raffles, T.S. 2014. The History of Java. Yogyakarta: Narasi

Rahmat, M. I. (Ed). 2003. Islam Pribumi: Mendialogkan Agama Membaca Realitas. Jakarta: Erlangga 
Riklefs, MC. 2005. Sejarah Indonesia Modern 1200-2004. Jakarta: Serambi Ilmu Semesta

Riklefs, MC. 2013. Mengislamkan Jawa: Sejarah Islamisasi di Jawa dan Penentangnya dari 1930 sampai Sekarang. Jakarta: Serambi

Said, E.C. 2010. Orientalisme: Menggugat Hegemoni Barat dan Mendudukkan Timur sebagai Subyek.Yogyakarta: Pustaka Pelajar

Soeratman, D. 1989. Kehidupan Dunia Kraton Surakarta 1830-1939. Yogyakarta: Penerbit Taman Siswa

Stockdale, J.J. 2010. Eksotisme Jawa: Ragam Kehidupan Masyarakat Jawa. Yogyakarta: Progresif Book

Suwarno. 2012. Dinamika Sejarah Asia Selatan. Yogyakarta: Ombak

Thorn, W. 2004. Penaklukan Pulau Jawa: Pulau Jawa di Abad Sembilan Belas dari Amatan Seorang Serdadu Kerajaan Inggris. Jakarta: Elex Media Komputindo

Tjandrasasmita, U. 2009. Arkeologi Islam Nusantara. Jakarta: KPG

Van Leur, J.C. 2015. Perdagangan dan Masyarakat Indonesia: Esai-Esai tentang Sejarah Sosial dan Ekonomi Asia. Yogyakarta: Ombak

Van Niel, R. 1956. "Reviewed Work: Indonesian Trade and Society. Essays in Asian Social and Economic History. by J. C. van Leur". The Far Eastern Quarterly. Vol. 15, No. 3, (1956): 440-441

Van Peursen, C.A. 1988. Strategi Kebudayaan. Yogyakarta: Kanisius

Vlekke, B.H.M. 2008. Nusantara: Sejarah Indonesia. Jakarta: KPG

Weber, M. 2002. Teori Dasar Analisis Kebudayaan. Yogyakarta: IRCISoD

Wertheim, W.F. 1954. "Early Asian Trade: An Appreciation of J.C. van Leur". The
Far Eastern Quarterly. Vol. 13, No.2 (1954): 167-173

Wertheim, W.F. 1963. "Asian history and the Western historian. Rejoinder to Professor Bastin". Bijdragen tot de Taal-, Land- en Volkenkunde. Vol.119, No.2 (1963): 149-160

Wertheim, W.F. 2009. Elite versus Massa. Yogyakarta: Resist Book

Wertheim, W.F., et.al (Eds). 1967. "Foreword of van Leur's work". J.C. van Leur. Indonesian Trade and Society: Essays in Asian Social and Economic History. The Hague: W. Van Hoeve

Wijaya, D.N. 2014. "John Locke dalam Demokrasi”. Jurnal Sejarah dan Budaya. Vol.8, No.1 (2014): 13-24 